\title{
Penerapan Metode Inversi Dalam Pendugaan Nilai Resistivitas
}

\author{
Application of the Inversion Method in Estimating the Resistivity \\ Value
}

\author{
Octavia Melani $^{1 *}$, Trias Annisa Fara ${ }^{1}$, Lola Anjelika ${ }^{1}$, Diah Ega \\ Safitri $^{1}$, Rahmat Catur Wibowo ${ }^{1}$, Ahmad Zaenudin ${ }^{1}$
}

${ }^{1}$ Jurusan Teknik Geofisika Fakultas Teknik Universitas Lampung

Email: octaviamelani02@gmail.com

\begin{abstract}
Abstrak
Pemodelan inversi (inverse modeling) sering disebut sebagai "kebalikan" dari pemodelan ke depan dikarenakan dalam pemodelan inversi parameter model didapatkan secara langsung dari data. Pemodelan inversi sering juga disebut dengan data fitting karena pada prosesnya mencari parameter model yang menghasilkan respons yang fit dengan data pengamatan. Tujuan utama metode inversi pada umunnya bukan untuk mengetahui secara keseluruhan bentuk dari permukaan fungsi obyektif pada ruang model, melainkan untuk mencari nilai minimum. Penelitian ini dilakukan untuk mengetahui resistivitas struktur bawah permukaan terhadap kedalaman dengan melakukan pengukuran-pengukuran dan perhitungan geofisika. Metode yang dilakukan yaitu dengan interpretasi menggunakan software dalam melakukan pengolahan data pengukuran geolistrik resistivitas VES dan tomografi. Data diolah dan di proses menggunakan bantuan perangkat lunak (software) yaitu, software Ipi2win untuk data VES dan software Res2div untuk data tomografi. Hasil penelitian ini diketahui bahwa batuan pirit (Pyrite) memiliki nilai resistivity 0,01-100, batu tulis (Shale) memiliki nilai resistivity 20-2000, pasir (Sand) memiliki nilai resistivity 1-1000, lempung (Clay) memiliki nilai resistivity 1100, air tanah (ground water) memiliki nilai resistivity 0,5-300, Aluvium memiliki nilai resistivity 10-800, dan Kerikil (Gravel) memiliki nilai resistivity 100-600. Sehingga dapat disimpulkan bahwa hasil tersebut kurang akurat karena tidak stabilannya nilai resistivity yang ada dan didapati error sebesar 38,7\%.
\end{abstract}

Kata kunci: Metode Inversi, Resistivitas, Software IP2Win, Software Res2div

\begin{abstract}
Inverse modeling is often referred to as the "reverse" of forward modeling because in inversion modeling the model parameters are obtained directly from the data. Inversion modeling is often referred to as data fitting because in the process it looks for model parameters that produce a response that fits the observed data. The main purpose of the inversion method in general is not to find out the overall shape of the surface of the objective function in the model space, but to find the minimum value. This research was conducted to determine the resistivity of the subsurface structure to depth by carrying out geophysical measurements and calculations. The method used is interpretation using software in processing VES resistivity and tomography geoelectrical measurement data. The data is processed and processed using software assistance, namely, Ipi2win software for VES data and Res2div software for tomographic data. The results of this study indicate that pyrite rock (Pyrite) has a resistivity value of 0.01-100, slate (Shale) has a resistivity value of 20-2000, sand (Sand) has a resistivity value of 1-1000, clay (Clay) has a resistivity value of $1-100$, ground water has a resistivity value of 0.5-300, Alluvium has a resistivity value of 10-800, and Gravel has a resistivity value of 100-600. So it can be concluded that the results are less accurate because of the unstable value of the existing resistivity and an error of $38.7 \%$ was found.
\end{abstract}




\section{PENDAHULUAN}

Metode geofisika merupakan metode terapan dari beberapa prinsip fisika yang bertujuan untuk mengetahui dan memecahkan masalah yang berhubungan dengan bumi. Beberapa persoalan fisika yang sering kali dihadapi memiliki kerumitan dalam penyelesaian matematisnya yaitu secara analitik maka dapat dengan disederhanakan penyelesaiannya dengan menggunakan pendekatan komputasi [1].

Gejala fisika yang menarik adalah permasalahan dalam bidang geofisika salah satunya yakni penentuan struktur bawah permukaan yaitu menentukan potensi sumber panas bumi. Penentuan struktur bawah permukaan dapat dilakukan dengan menerapkan metode inversi dengan pendekatan Gauss Jordan. Proses inversi adalah suatu proses pengolahan data lapangan yang melibatkan teknik penyelesaian matematika dan statistik untuk mendapatkan informasi yang berguna mengenai distribusi sifat fisik bawah permukaan [2].

Dalam mencari sumber daya alam yang keberadaannya sangat penting untuk perkembangan peradaban manusia, peranan geofisika menjadi sangat diperlukan mengingat sumber daya yang masih ada umumnya tersembunyi di bawah endapan hasil erosi sehingga tidak mungkin lagi teramati secara geologis. Karena itulah mengapa ilmu geofisika telah berkembang begitu cepat. Walaupun ilmu geoflsika termasuk ilmu fişika, namun metodologinya telah bergeser dari metodologi yang biasa dipakai dalam mempelajari ilmu fisika menjadi metode-metode geofisika seperti metode inversi geofisika [3].

Tujuan utama dari kegiatan eksplorasi geofisika adalah untuk membuat model bawah permukaan bumi dengan mengandalkan data lapangan yang diukur bisa pada permsukaan bumi atau di bawah permukaan bumi atau bisa juga di atas permukaan bumi dari ketinggian tertentu. Untuk mencapai tujuan ini, idealnya kegiatan survey atau pengukuran harus dilakukan secara terus menerus, berkelanjutan dan terintegrasi menggunakan sejumlah ragam metode geofisika [2].

Seringkali bahkan hampir pasti terjadi beberapa kendala akan muncul dan tak bisa dihindari, seperti kehadiran noise pada data yang diukur. Ada juga kendala tidak lengkapan data atau malah kurang alias tidak cukup. Namun demikian, dengan analisis data yang paling mungkin, kita berupaya memperoleh informasi yang relatif valid berdasarkan keterbatasan data yang kita miliki. Dalam melakukan analisis, sejumlah informasi mengenai kegiatan akuisisi data juga diperlukan, antara lain: nilai sampling rate yang optimal, jumlah data yang diperlukan, berapa tingkat akurasi yang diinginkan. Selanjutnya pemilihan proses analisis model matematika yang cocok mesti ditentukan mana yang akan berperan ketika menghubungkan antara data lapangan dan distribusi parameter fisis yang hendak dicari [2].

Seperti yang kita ketahui bahwa tujuan dari proses inversi yaitu untuk mengestimasi parameter fisis batuan yang sebelumnya tidak diketahui (unknow parameter). Proses inversi terbagi dalam level-level tertentu mulai dari yang paling sederhana seperti fitting garis untuk data seismik refraksi sampai kepada level yang rumit seperti tomografi akustik dan matching (pencocokan) kurva resistivity yang multidimensi. Sehingga, tujuan dari penelitian ini ialah untuk mengetahui resistivitas struktur bawah permukaan terhadap kedalaman dengan melakukan pengukuran-pengukuran dan perhitungan geofisika dan untuk mendapatkan hasil pendugaan nilai resistivitas dengan penyusunan elektroda dalam bermacammacam konfigurasi [4].

Dalam bidang ilmu geofisika, akuisisi data lapangan pasti dilakukan sesuai dengan 
prosedur yang sudah ditentukan sebelumnya. Data hasil pengukuran dicatat lalu disajikan dalam bentuk tabel angkaangka atau tabel data pengukuran. Kemudian, hasil pengukuran berupa data tersebut memiliki nilai error yang dipengaruhi oleh beberapa hal terutama tergantung pada kondisi dan sifat fisis batuan bawah permukaan. Data berupa angka-angka yang mememiliki noise disebut data lapangan. Metode inversi merupakan suatu proses pengolahan data lapangan atau data observasi yang menggunakan teknik penyelesaian masalah secara matematika dan statistik untuk mendapatkan hasil berupa informasi yang dapat diguankan untuk menganalisis proses ditribusi sifat fisis bawah permukaan. Di dalam proses inversi, analisis dilakukan terhadap data observasi dengan cara melakukan curve fitting (pencocokan kurva) antara model matematika dan data observasi atau data lapangan [2].

Dalam explorasi geofisika terdapat beberapa metode yang bisa digunakan. Terkhusus untuk penyelidikan bawah permukaan tanah yang dapat dilakukan, diantaranya ada metode geologi, metode gravitasi, metode magnit, metode seismik, dan metode geolistrik. Dari metode-metode tersebut, metode geolistrik merupakan metode yang banyak sekali digunakan dan hasilnya cukup baik [5].

Salah satu metode geofisika yang sering digunakan pada proses akuisisi data lapangan adalah metode geolistik. Metode geolistrik biasa digunakan dalam proses penentuan akuifer air tanah, mencari lokasi patahan, eksplorasi mineral dalam tanah dan ekplorasi arkeologi. Metode ini didasari oleh asumsi teruji bahwa material yang berbeda akan memiliki nilai resistivitas yang berbeda ketika dialiri arus listrik. Salah satu metode geolistrik yang sering digunakan dalam pengukuran aliran listrik dan untuk mempelajari keadaan geologi bawah permukaan adalah metode resistivitas [6].
Resistivitas adalah suatu sifat fisis yang dimiliki batuan, berupa kemampuan untuk dilewati dan dialiri arus listrik, jika batuan makin sukar atau semakin sulit untuk dilewati oleh arus listrik maka semakin besar nilai resistivitas batuan tersebut begitupun sebaliknya apabila semakin mudah dilalui arus listrik maka semakin kecil nilai resistivitasnya. Pada metode geolistrik, arus listrik diinjeksikan atau dialirkan ke dalam bumi melalui dua elektroda arus, kemudian menukur beda potensial menggunakan dua elektroda. Tujuan survey geolistrik resistivitas adalah untuk mengetahui resistivitas bawah permukaan bumi dengan melakukan pengukuran pada permukaan bumi. Pendekatan yang paling sederhana dalam mempelajari aliran arus listrik di dalam bumi adalah bumi dianggap homogen isotropis. Homogen isotropis sendiri adalah asumsi atau anggapan bahwa bumi memiliki satu lapisan batuan dengan nilai resistivitas yang sama [6].

Prinsip dasar dari metode resistivitas adalah penggunaan arus untuk menginvestigasi sifat listrik (tahanan jenis) dari bawah permukaan. Pengukuran resistivitas dilakukan dengan menginjeksi arus menggunakan dua elektroda (disebut elektroda arus) dan mengukur beda potensial dari dua elektroda lainnya, yang disebut elektroda potensial. Dengan begitu kita dapat mengetahui nilai arus dan beda potensial, maka nilai tahanan jenis atau resistivitas dapat diketahui juga. Nilai resistivitas dari pengukuran ini disebut dengan resistivitas semu (apparent resistivity) [7].

Metode resistivitas memiliki beberapa konfigurasi atau susunan elektroda, yaitu pole-pole, dipole-dipole, pole-dipole, Wenner, Schlumberger, dan WennerSchlumberger. Penggunaan konfigurasi disesuaikan dengan apa yang akan dicari pada saat survei geofisika. Metode resistivitas merupakan metode yang sensitif terhadap perubahan lengas tanah dan efektif 
untuk menentukan kedalaman untuk daerah air jenuh dan pola aliran air tanah. Seperti yang sudah dijelaskan sebelumnya data observasi atau data lapangan mengandung noise. Noise atau disebut juga derau adalah sinyal-sinyal yang tidak diinginkan atau tidak dikehendaki keberadaannya namun ikut termasuk kedalam data yang dihasilkan pada saat pengukuran, dimana keberadaannya dalam suatu sistem atau data dapat mempengaruhi keakuratan data tersebut. terdapat beberapa hal yang memengaruhi resistivitas tanah, antara lain saturasi, porositas, permeabilitas, kandungan ion dari fluida, dan kandungan lumpur [7].

Salah satu permasalahan dalam pengukuran metode resistivitas adalah permasalahan pada bumi yang bersifat tak homogen walau bisa dipecahkan dengan asumsi bumi bersifat homogen pada kenyataannya, bumi tersusun oleh material yang berbeda pada setiap lapisannya. Material penyusun lapisan bumi tentunya memiliki sifat kelistrikan yang berbeda satu dengan yang lainnya. Hal ini berarti potensial listrik yang terukur merupakan harga potensial listrik total dari semua jenis lapisan yang dilewati arus listrik. Dengan demikian, harga resistivitas yang terukur juga merupakan harga resistivitas total atau disebut resistivitas semu (apparent resistivity) [8].

Pemodelan inversi merupakan suatu metode yang digunakan dalam interpretasi komputer untuk memodelkan suatu data yang dimasukkan ke dalamnya. Proses pemodelan akan dilakukan secara otomatis untuk mendapatkan suatu model atau suatu nilai yang dicari. Salah satu program komputer yang menggunakan metode inversi untuk memodelkan data adalah program RES2DINV. Program RES2DINV merupakan program yang dilengkapi dengan metode iteratif smoothness- constrained dan least-squares. Dalam melakukan pemodelan inversi untuk menghasilkan sebuah gambaran (peta) formasi lapisan batuan 2-D (dua dimensi) dan nilai resistivitas tiap lapisan batuan berdasarkan data resistivitas semu [8].

\section{METODE PENELITIAN}

Untuk menentukan inversi resistivitas digunakan pendekatan inversi nonlinear, sehingga, metode inversi yang digunakan untuk menyelesaikan perhitungan ini digunakan metode Gauss, yakni pendekatan deret taylor. Nilai resisitivitas semu yang kita miliki akan diubah menjadi resisitivitas sebenarnya dengan teknik inverse modeling. Proses inversi dilakukan dengan menggunakan software IP2Win. Proses inversi dilakukan untuk mengubah nilai resistivitas semu menjadi nilai resistivitas material sebenarnya sehingga didapatkan nilai resistivitas sebenarnya.

\section{HASIL DAN PEMBAHASAN}

Resistivitas adalah suatu sifat fisis yang dimiliki batuan, berupa kemampuan untuk dilewati dan dialiri arus listrik, jika batuan makin sukar atau semakin sulit untuk dilewati oleh arus listrik maka semakin besar nilai resistivitas batuan tersebut begitupun sebaliknya apabila semakin mudah dilalui arus listrik maka semakin kecil nilai resistivitasnya. Prinsip dasar dari metode resistivitas adalah penggunaan arus untuk menginvestigasi sifat listrik (tahanan jenis) dari bawah permukaan. Pengukuran resistivitas dilakukan dengan menginjeksi arus menggunakan dua elektroda (disebut elektroda arus) dan mengukur beda potensial dari dua elektroda lainnya, yang disebut elektroda potensial. Dengan begitu kita dapat mengetahui nilai arus dan beda potensial, maka nilai tahanan jenis atau resistivitas dapat diketahui juga. Nilai resistivitas dari pengukuran ini disebut dengan resistivitas semu (apparent resistivity). 
Pemodelan inversi merupakan suatu metode yang digunakan dalam interpretasi untuk memodelkan suatu data. Proses pemodelan akan dilakukan secara otomatis untuk mendapatkan suatu model atau suatu nilai yang dicari. Dalam melakukan pemodelan inversi untuk menghasilkan sebuah gambaran (peta) formasi lapisan batuan 2-D (dua dimensi) dan nilai resistivitas tiap lapisan batuan berdasarkan data resistivitas semu dari data lapangan.

Apparent resistivity pseudosection merupakan penampang melintang semu yang menggambarkan distribusi nilai resistivitas semu suatu titik VES terhadap titik VES lainnya dibawah permukaan bumi. Penampang melintang semu tersebut memiliki absis jarak antar titik VES satu dengan titik VES lainnya dan ordinat nilai $\mathrm{AB} / 2$ atau 1/2L. kordinat tidak menunjukkan kedalaman sebenarnya namun menunjukkan kedalaman semu. Faktor konversi untuk mengubah kedalaman semu tersebut menjadi kedalaman sebenarnya dapat berkisar antara 0.33 hingga 0.14 .

Susunan elektroda yang dilaksanakan di lapangan untuk pengambilan data geolistrik VES menggunakan susunan elektroda konfigurasi wenner. Pengukuran VES dilakukan secara manual, dengan memindahkan 4 elektroda bersamaan untuk setiap kedalaman. Susunan elektroda yang biasa digunakan adalah wennerschlumberger dengan jarak antar elektroda atau spasi elektroda $10 \mathrm{~m}$. Data hasil pengukuran geolistrik resistivitas diolah dengan menggunakan dua teknik intepretasi yaitu, teknik intepretasi secara manual dengan menggunakan teknik kurva matching, metode lapisan Barnes dan Kumulatif Moore. Dan teknik intepretasi dengan menggunakan software yaitu, Ipi2win untuk data sounding dan Res2divn untuk data tomografi. Secara umum tahapan-tahapan pengolahan data geolistrik resistivitas dengan teknik intepretasi manual dan software.
Teknik intepretasi manual dilakukan dengan cara perbandingan kurva, secara umum pengolahan data geolistrik VES ini dilakukan dengan teknik curve matching (pencocokkan kurva), yaitu dengan mencocokan data observasi atau data lapangan dengan kurva standar (baku) yang telah ada untuk mengetahui susunan litologi bawah permukaan secara vertikal. Tidak semua titik duga menghasilkan lengkung (kurva) yang dapat diintepretasikan, maka disamping pembuatan lengkung duga juga dilakukan perhitungan resistivitas murni dengan metode lapisan Barnes untuk setiap kedalaman $10 \mathrm{~m}$. Hasilnya menggambarkan perubahan litologi bardasarkan resistivitasnya. Selain itu dilakukan perhitungan dengan menggunakan Kumulatif Moore, untuk memperoleh gambaran batas lapisan litologi.

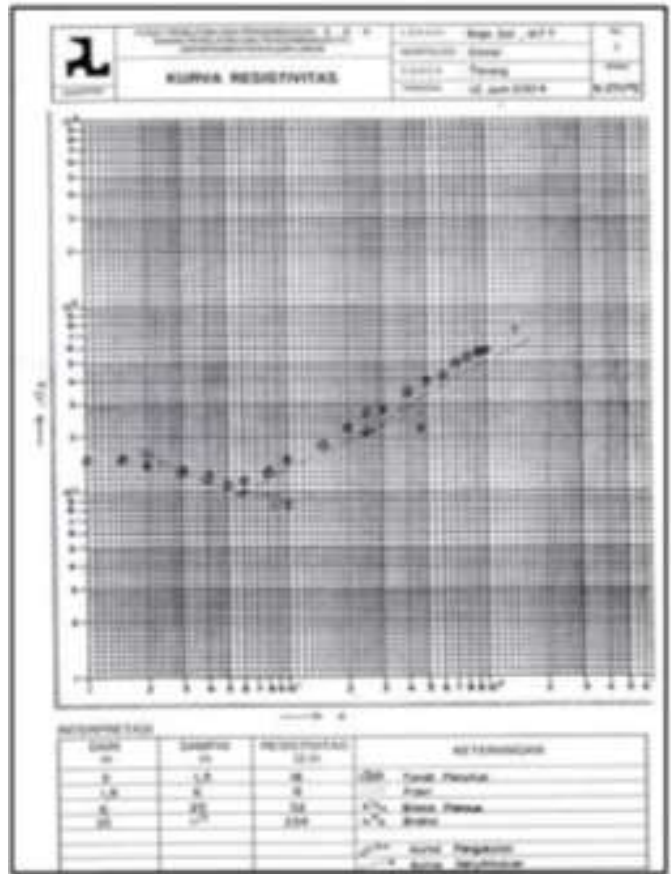

Gambar 1. Interpretasi Nilai Resistivitas Secara manual 


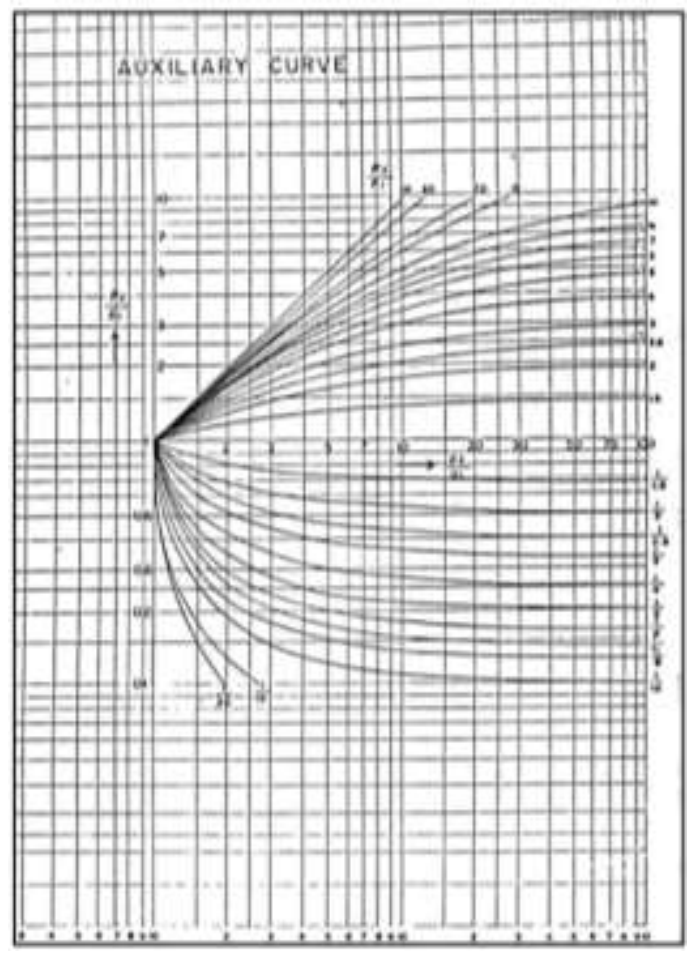

Gambar 2. Kurva bantu untuk konfigurasi wenner

\begin{tabular}{|c|c|c|c|c|}
\hline \multicolumn{5}{|c|}{ 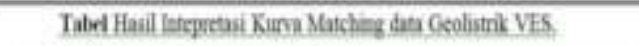 } \\
\hline No & $\begin{array}{c}\text { Kethamina } \\
\text { (imi) }\end{array}$ & $\begin{array}{c}\text { Resiativius } \\
\text { (Smin) }\end{array}$ & $\begin{array}{l}\text { Ketchalus } \\
\text { (m) }\end{array}$ & Keteangan \\
\hline 1 & $0.4,2$ & 100 & 4 & Tanah Pesaump (Iop Sill) \\
\hline 2 & $42+20$ & 12.5 & 15.8 & 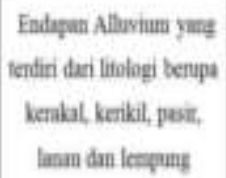 \\
\hline 3 & $20 \cdot x$ & 375 & & Btmpesir \\
\hline
\end{tabular}

Gambar 3. Tabel hasil intepretasi pencocokkan kurva data geolistrik VES

Intepretasi menggunakan software dilakukan dengan melakukan pengolahan data pengukuran geolistrik resistivitas VES dan tomografi. Data diolah dan di proses menggunakan bantuan perangkat lunak (software) yaitu, software Ipi2win untuk data VES dan software Res2div untuk data tomografi.

Prinsip yang digunakan pada interpretasi manual dan dengan software itu sama dimana pengolahan data VES dengan sama dengan kurva matching, yaitu dengan mencocokkan kurva plot data lapangan dengan kurva model (kurva standar). Namun yang membedakannya pada software Ipi2win, hasil pencocokkan kurva ditentukan oleh proses inversi yang bekerja dengan algoritma tertentu. Dari hasil kurva resistivitas 1D ini kemudian dibuat penampang resistivitas 2D. Setiap warna mewakili suatu nilai resistivitas tertentu. Untuk mengintepretasi struktur litologi bawah permukaan dibawah titik pengukuran, dilakukan dengan melihat citra perlapisan berwarna ini sebagai fungsi kedalaman. Dari hasil analisis ini, dapat diketahui gambaran litologi bawah permukaan dibawah titik pengukuran dan dapat diduga lapisan yang bertindak sebagai sebagai akuifer. Sedangkan pengolahan data tomografi dengan menggunakan software Res2divn bertujuan untuk membuat suatu model penampang bawah permukaan secara lateral dan vertikal sekaligus, baik dalam bentuk 2D atau 3D, dimana model penampang tersebut mencerminkan distribusi nilai resistivitas sebenarnya dibawah permukaan bumi (dibawah titik pengukuran) dan kedalaman lapisan. Hasil penampang pada Res2divn diperoleh dari hasil inversi nilai apparent resistivity.

Proses inversi terbagi dalam level-level tertentu mulai dari yang paling sederhana seperti fitting garis untuk data seismik refraksi sampai kepada level yang rumit seperti tomografi akustik dan matching (pencocokan) kurva resistivity yang multidimensi. Proses inversi dilakukan untuk mengubah nilai resistivitas semu menjadi nilai resistivitas material sebenarnya sehingga didapatkan nilai resistivitas sebenarnya.

Proses inversi dilakukan pada nilai resitivitas semu menggunakan software IP2Win untuk mendapatkan nilai resistivitas sebenarnya. Hasil inversi adalah tabel nilai resistivitas yang mencakup informasi nilai resistivitas yang sebenarnya dan distribusinya menurut kedalaman dari 
permukaan Bumi. Nilai resistivitas sebenarnya merupakan nilai resistivitas yang dapat diinterpretasi karena nilai tersebut disertai dengan informasi distribusinya menurut kedalaman di bawah permukaan Bumi. Nilai resisitivitas sebenarnya berbeda dengan nilai resistivitas semu yang tidak memiliki informasi kedalaman melainkan hanya memiliki nilai $\mathrm{AB} / 2$ atau $1 / 2 \mathrm{~L}$ yang menunjukkan jarak antar pasangan elektroda arus dan potensial atau nilai kedalaman semu.

Salah satu program komputer yang menggunakan pemodelan inversi untuk memodelkan data adalah program RES2DINV. Program RES2DINV merupakan program yang dilengkapi dengan metode iteratif smoothness- constrained dan least-squares. Dalam melakukan pemodelan inversi untuk menghasilkan sebuah gambaran (peta) formasi lapisan batuan 2-D (dua dimensi) dan nilai resistivitas tiap lapisan batuan berdasarkan data resistivitas semu yang sebelumnya didapatkan dari lapangan.

Misal kita memiliki Rho $1=0,1$; Rho 2 $=0,5 ;$ Rho $3=1,0$ Respon yang diapat yaitu:

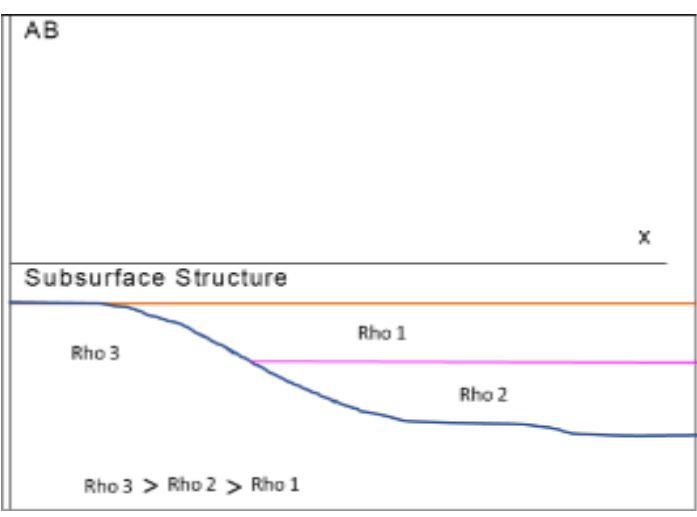

Gambar 4. Struktur Perlapisan

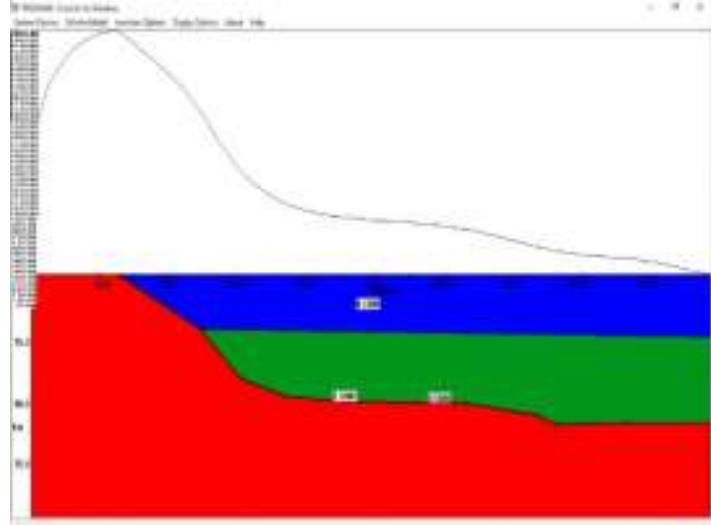

Gambar 5. Respon perlapisan

Dari penampang diatas dapat kita ketahui bentuk perlapisan dibawah permukaan bumi dengan mengetahui nilai Rho perlapisannya. Pada suatu daerah $\mathrm{X}$ diketahui hasil pengukuran geolistrik adalah sebagai berikut:

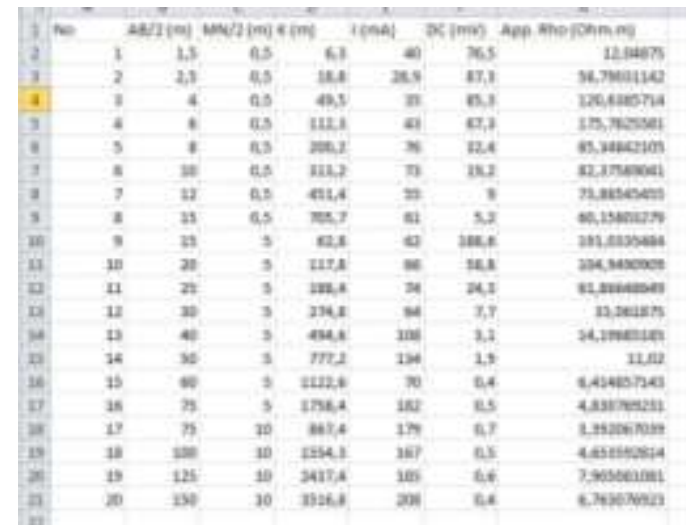

Gambar 6. Data hasil pengukuran

Dari data diatas dapat kita ketahui kurva nilai restivititas semu (garis warna hitam) dan kurva perhitungan kalkulatis (garis warna merah), dan forwhat modeling di bawah perhitungan (garis warna biru). Gunanya untuk mengatur kurva perhitungan berhimpit dengan kurva resistivitas semu dengan eror tidak lebih dari $20 \%$ ). 


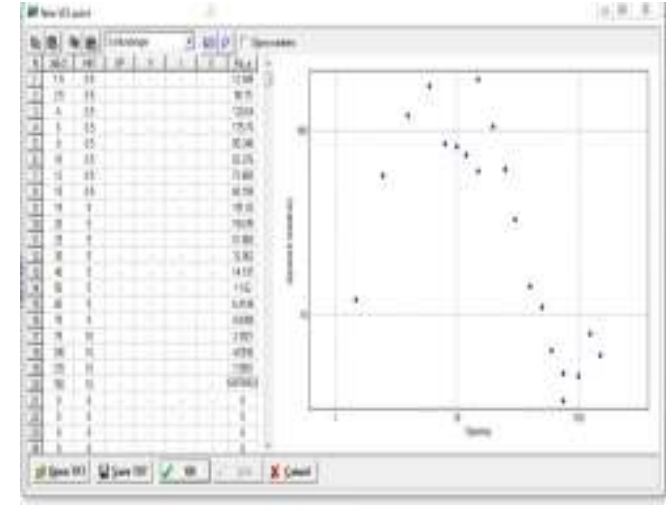

Gambar 7. Kurva resistivitas semu

Pada tabel yang ditunjukkan oleh gambar. 3 memberikan informasi tentang resistivity layer. Kolom $\rho$ adalah nilai resistivitas (hambatan) tiap lapisan. Kolom Alt adalah altitude atau kedalaman dari elevasi (ketinggian) titik VES Kolom d memberikan informasi tentang kedalaman dari permukaan tanah. Kolom h memberikan informasi tentang ketebalan tiap lapisan dengan nilai resistivitas yang berbeda. Grafik warna hitam dan merah memberikan informasi tentang hubungan nilai $\mathrm{AB} / 2$ dan apparent resistivity, grafik warna biru memberikan informasi tentang variasi dari nilai resistivitas yang ada. Salah satu permasalahan dalam pengukuran metode resistivitas adalah permasalahan pada bumi yang bersifat tak homogen walau bisa dipecahkan dengan asumsi bumi bersifat homogen pada kenyataannya, bumi tersusun oleh material yang berbeda pada setiap lapisannya. Hal ini berarti potensial listrik yang terukur merupakan harga potensial listrik total dari semua jenis lapisan yang dilewati arus listrik. Dengan demikian, harga resistivitas yang terukur juga merupakan harga resistivitas total atau disebut resistivitas semu (apparent resistivity).

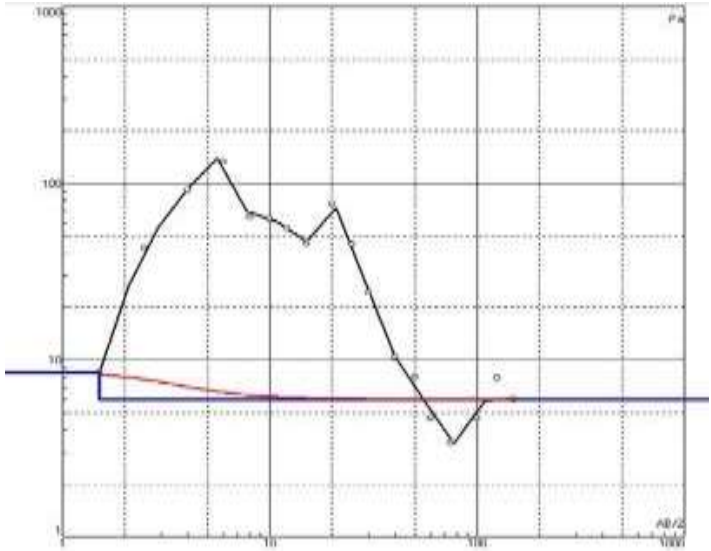

Gambar 8. Grafik nilai resistivitas

Dari gambar diatas telihat bahwa nilai error yang ada masih cukup besar menggunakan metode inversi pada software IPIIWin nialai error tersebut bisa dikecilkan, sehingga resistivitas semua tersebut dapat diketahui resiistivitas sebenarnya.

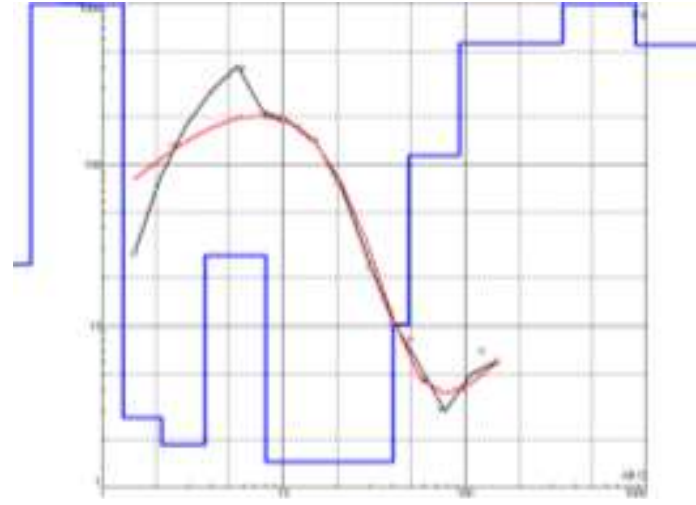

Gambar 9. Grafik hasil pengolahan

Menggunakan Software IPI2Win kita bisa melihat lapisan resistivitas pada data lapangan degan Window information pada coordinate table kolom $\mathrm{N}$ dan jumlah titik yang digabungkan dan pilih array tipe dari dua data yang digabungkan tersebut, pilih schlumberger karena sesuai dengan konfigurasi elektroda dari awal yang dimasukan, kemudian klik OK. Akan muncul tabel dan lapisan warna-warni seperti pada gambar dibawah ini yang merupakan distribusi nilai resitivita secara vertikal dari dua VES yang telah di interpolasi, lapisan warna-warni tersebut adalah pseudo cross section dari titik 
pertama dan kedua.

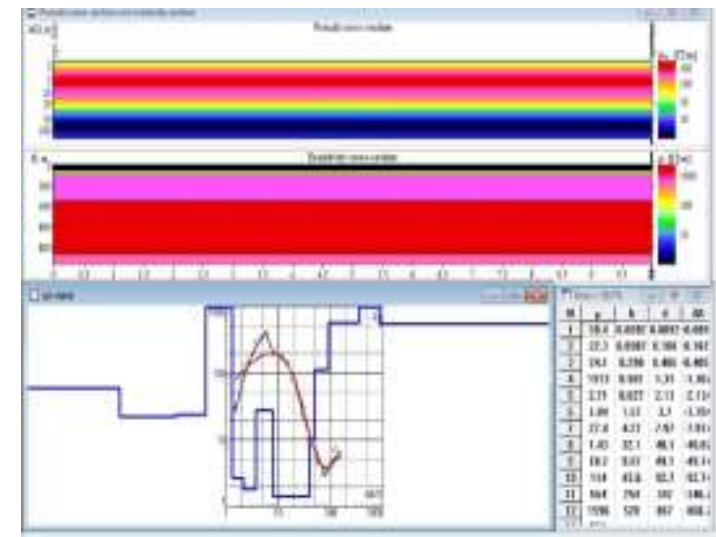

Gambar 10. Proses pengolahan data

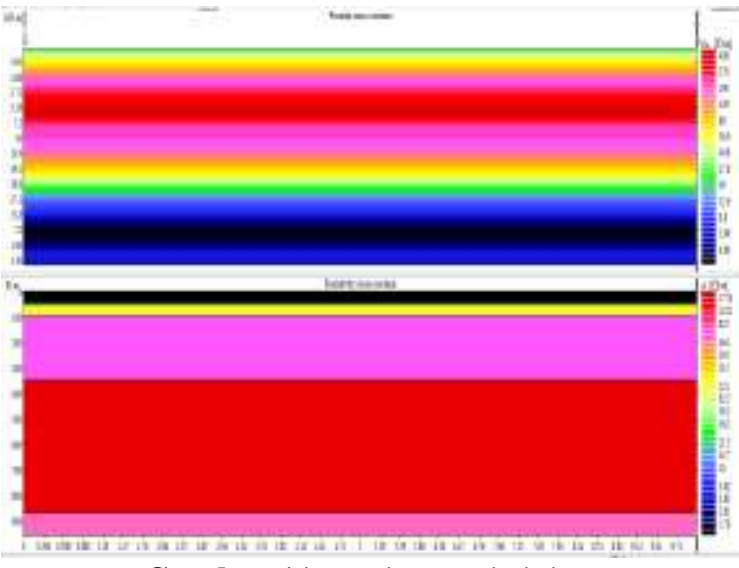

Gambar 11. Lapisan resistivitas

Setelah data diolah menggunakan Software IPI2Win hasil dapat dilihat dari gambar di atas, kurva matching pada Gambar 6 dan Gambar 7 hampir berhimpit dengan eror sebesar 38,7\% yang menunjukan bahwa data ini tidak cukup akurat karena besar eror dari data ini diatas $20 \%$, seperti yang kita ketahui bahwa data yang memiliki eror dibawah $20 \%$ akan lebih akurat daripada yang memiliki eror diatas $20 \%$. Pada penampang menunjukan bahwa lapisan pertama memiliki kedalaman dari permukaan tanah sebesar 0,0092 $\mathrm{m}$, ketebalan lapisan $0,0092 \mathrm{~m}$ dengan nilai resistivitas sebesar $59,4 \Omega \mathrm{m}$, pada lapisan kedua memiliki kedalaman dari permukaan tanah sebesar 0,108 m, ketebalan lapisan 0,0987 $\mathrm{m}$ dengan nilai resistivitas sebesar 22,3 $\Omega \mathrm{m}$, pada lapisan ketiga memiliki kedalaman dari permukaan tanah sebesar 0,406 m, ketebalan lapisan 0,298 m dengan nilai resistivitas sebesar $24,1 \Omega \mathrm{m}$, pada lapisan keempat memiliki kedalaman dari permukaan tanah sebesar 1,31 m, ketebalan lapisan $0,901 \mathrm{~m}$ dengan nilai resistivitas sebesar $1.913 \Omega \mathrm{m}$, pada lapisan kelima memiliki kedalaman dari permukaan tanah sebesar 2,13 m, ketebalan lapisan 0,827 m dengan nilai resistivitas sebesar 2,71 $\Omega \mathrm{m}$.

\begin{tabular}{|c|c|}
\hline Material & Resistivitas ( $\mathbf{Q m})$ \\
\hline Udara (Air) & - \\
\hline Pirit (Pyrite) & $0.01-100$ \\
\hline Kwarsa (Quartz) & $500-800000$ \\
\hline Kalsit (Calcite) & $1 \times 10^{12}-1 \times 10^{13}$ \\
\hline Garam Batu (Rock salt) & $30-1 \times 10^{13}$ \\
\hline Granit (Granite) & $200-10000$ \\
\hline Andesit (Andesite) & $1.7 \times 10^{2}-45 \times 10^{4}$ \\
\hline Basal (Basaln) & $200-10.0000$ \\
\hline Gamping (Limestone) & $500-10000$ \\
\hline Batu pasir (Sandstone) & $200-8000$ \\
\hline Batu tulis (Shiales) & $20-2000$ \\
\hline Pasir (Sand) & $1-1000$ \\
\hline Lempung (Clav) & $1-100$ \\
\hline $\begin{array}{l}\text { Air tanah (Ground } \\
\text { water) }\end{array}$ & $0.5-300$ \\
\hline Air asin (Sea water) & 0.2 \\
\hline Magnetit (Magnetite) & $0.01-1000$ \\
\hline $\begin{array}{l}\text { Kerikil kering (Dry } \\
\text { gravel) }\end{array}$ & $600-10000$ \\
\hline Aluyium (Allıvium) & $10-800$ \\
\hline Kerikil (Gravel) & $100-600$ \\
\hline
\end{tabular}

Gambar 12. Nilai Resistivitas Batuan

Pada lapisan keenam diketahui memiliki kedalaman dari permukaan tanah sebesar 3,7 m, ketebalan lapisan 1,57 m dengan nilai resistivitas sebesar $1,84 \Omega \mathrm{m}$, pada lapisan ketujuh memiliki kedalaman dari permukaan tanah sebesar 7,97 $\mathrm{m}$, ketebalan lapisan 4,27 m dengan nilai resistivitas sebesar $27,4 \Omega \mathrm{m}$, pada lapisan kedelapan memiliki kedalaman dari permukaan tanah sebesar 40,1 m, ketebalan lapisan $32,1 \mathrm{~m}$ dengan nilai resistivitas sebesar 1,43 $\Omega \mathrm{m}$, pada lapisan kesembilan memiliki kedalaman dari permukaan tanah sebesar 49,1 m, ketebalan lapisan 9,07 m 
dengan nilai resistivitas sebesar $10,2 \Omega \mathrm{m}$, pada lapisan kesepuluh memiliki kedalaman dari permukaan tanah sebesar $92,7 \mathrm{~m}$, ketebalan lapisan 43,6 m dengan nilai resistivitas sebesar $144 \Omega \mathrm{m}$, pada lapisan kesebelas memiliki kedalaman dari permukaan tanah sebesar $347 \mathrm{~m}$, ketebalan lapisan $254 \mathrm{~m}$ dengan nilai resistivitas sebesar $564 \Omega \mathrm{m}$, dan pada lapisan keduabelas memiliki kedalaman dari permukaan tanah sebesar $867 \mathrm{~m}$, ketebalan lapisan $520 \mathrm{~m}$ dengan nilai resistivitas sebesar $1.596 \Omega \mathrm{m}$.

\section{KESIMPULAN}

Dari penelitian yang dilakukan dapat disimpulkan bahwa Penampang ini di peroleh rentang nilai resistivity 1,43-1.913 $\Omega \mathrm{m}$. Berdasarkan tabel nilai restivitas, diperkirakan material nya bisa saja pirit (Pyrite) dengan nilai resistivity 0,01-100, batu tulis (Shale) dengan nilai resistivity 202000, pasir (Sand) dengan nilai resistivity 11000, lempung (Clay) dengan nilai resistivity 1-100, air tanah (ground water) dengan nilai resistivity 0,5-300, Aluvium dengan nilai resistivity 10-800, dan Kerikil (Gravel) dengan nilai resistivity 100-600.

Dari semua kemungkinan material yang terdeteksi pada daerah 4 ini, hasil data nya masih kurang akurat karena tidak stabilanya nilai resistivity yang ada dan juga dipengaruhi oleh eror data yang sangat besar yaitu $38,7 \%$. Hal ini lah yang membuat kita tidak bisa dengan jelas mengetahui material apa saja yang ada di daerah ini.

[5] A. . Prakusya and R. S. . Waspodo, "Eksplorasi Air Tanah dengan Metode Tahanan Jenis Menggunakan," vol. 04, no. 02, pp. 102-114, 2019.

[6] T. N. Fitrianto, S. Supriyadi, and T. M. Mukromin, "Pencitraan 3D Data Geolistrik Resistivitas dengan Rockworks Berdasarkan Hasil Inversi Res2DInv untuk Mengetahui Persebaran Batuan Konglomerat di Desa Surodadi, Kecamatan Gringsing, Kabupaten Batang," Indones. J. Appl. Phys., vol. 7, no. 2, p. 111, 2017, doi: 10.13057/ijap.v7i2.13952.

[7] F. K. Ayu, "Pemanfaatan Metode Resistivitas Konfigurasi WennerSchlumberger Untuk Application of Resistivity Method WennerSchlumberger Array To Evaluate Brantas River Embankment As Avoiding," 2016.

[8] N. Dengen, "Pengolahan Data Geolistrik Pada Ekplorasi Sumber Air Tanah Di Kecamatan Kongbeng Kabupaten Kutai Timur 
Dengan Perangkat Lunak

Res2Dinv," J. Inform.

Mulawarman, vol. 7, no. 1, pp. 2734, 2012.

[9] Y. Afrizal et al., "ANALISIS KEKUATAN BETON PASCA BAKAR DENGAN METODE NUMERIK," Teknosia, vol. 1, no. 13, pp. 21-28.

[10] SK SNI 15-1991-03, "Tata Cara Perhitungai Struktur Beton Untuk Bangunan Gedung," Sk Sni T151991-03, p. 520, 1991. 